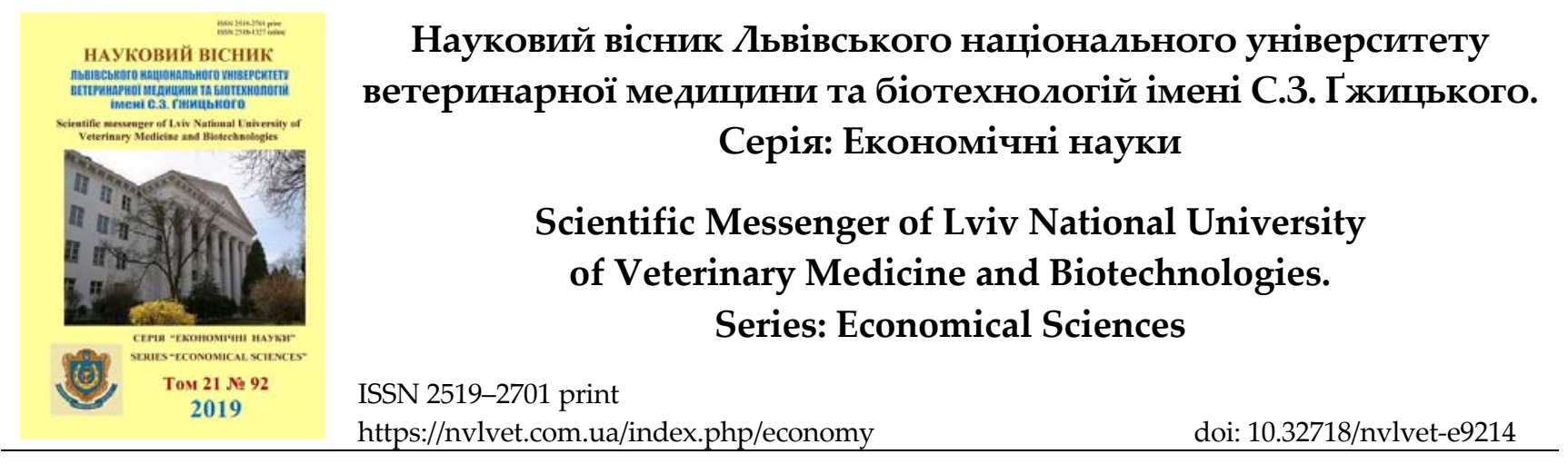

UDC 338.14

\title{
Management of assortment policy of the enterprise in market conditions
}

\author{
S.G. Kaflevska ${ }^{1}$, O.F. Tomchuk ${ }^{2}$ \\ ${ }^{1}$ Vinnitsia Cooperative Institute, Vinnitsia, Ukraine \\ ${ }^{2}$ Vinnitsia National Agrarian University, Vinnitsia,Ukraine
}

Article info

Received 30.01.2019

Received in revised form 04.03.2019

Accepted 05.03.2019

Vinnitsia Cooperative Institute, Akademika Yanhelia Str., 59 Vinnitsia, 21009, Ukraine. Tel.: +38-067-423-59-59 E-mail: svitlanakaflevska@ukr.net

Vinnytsia National Agrarian University, Soniachna Str., 3 Vinnytsia, 21008, Ukraine. Tel.: +38-096-014-67-65 E-mail: olenatomchuk@ukr.net
Kaflevska, S.G., \& Tomchuk, O.F. (2019). Management of assortment policy of the enterprise in market conditions. Scientific Messenger of Lviv National University of Veterinary Medicine and Biotechnologies. Series: Economical Sciences, 21(92), 90-95. doi: 10.32718/nvlvet-e9214

From the results of the assortment policy, it will depend on whether the company will have the opportunity to develop steadily, whether it will occupy leading positions in the markets, be able to compete effectively or fall into the crisis through unsuccessfully selected assortment and will strive to survive in a complex and saturated environment. That is, it may be noted that the assortment policy serves as a certain benchmark for making decisions that meet the requirements of the conditions of the functioning of the market entity. Thus, the chosen topic is very relevant in a market economy. The purpose of the study is to study the features of the modern assortment policy of enterprises in a highly competitive market and to develop measures for management decisions in the field of assortment policy of the enterprise. In order to achieve the goal, it is necessary to fulfill the following tasks: to study theoretical aspects of the management of the assortment policy of the enterprise; to define the basic methods of forming the assortment of production of the enterprise; to analyze methods of assortment policy according to criteria of managerial efficiency; outline measures to improve the company's product mix. In order to study the formation of the product range of the company used three main groupsmethods: methods of economic analysis; methods of determining consumer preferences; portfolio analysis methods. The object of research is PJSC "Vinnytsia Food Processing Factory", which produces more than 50 products: table horseradish; mustard; mayonnaise; sauces; ketchup; Corn sticks; breakfast cereals with fillings; quick-cooked cereals; flour textured; bread kvass; vinegar dining room "Vinnitsa"; pet pack. All production processes are carried out on modern hightech equipment of the leading European companies in strict conformity with the formulation and observance of all state standards. As a result of the analysis of the ABC rating of all products of PJSC "Vinnytsia Food Processing Factory", it was established that in 2017, the Group A of the strategic production group included such products as horseradish, mustard, sauces. The given group of products brings more than $78 \%$ of the proceeds in the investigated enterprise. Group B refers to the production of cereals. This group brings to the enterprise $15.7 \%$ of the total proceeds. The latest types of products in Group C do not significantly affect the overall proceeds from sales. For the company there are three main areas of gaining competitive advantages: to become the best, to weaken competitors or to change the market environment. The developed SWOT analysis matrix allows us to formulate a list of priority measures that the company should take to improve its marketing environment. Taking into account the strengths and weaknesses of PJSC "Vinnitsa Kharchosmakovaya Fabrika" and combining them with the identified opportunities, one can outline the following strategies for the development of the company: expansion of assortment and nomenclature of products; development of the system of personal sales for wholesalers of products; creation and distribution of free advertising and information materials on the activities of the company and the conduct of the advertising company; increasing the market share of the company by creating new products and conquering new segments of the market.

Key words: management, assortment policy, product, product range, quality, nomenclature, concept, strategy, marketing, market segment, market environment.

\section{Управління асортиментною політикою підприємства в ринкових умовах}

\author{
С.Г. Кафлевська ${ }^{1}$, О.Ф. Томчук ${ }^{2}$
}




\author{
${ }^{1}$ Вінницький кооперативний інститут, м. Вінниця, Украӥна \\ ${ }^{2}$ Вінницький національний аграрний університет, м. Вінниця, Украӥна
}

Від результатів запровадження асортиментної політики буде залежати чи підприємство матиме можливість стабільно розвиватися, чи займатиме лідируючі позичї на ринках, спроможне ефективно конкурувати чи потрапить у кризу через невдало підібраний асортимент та намагатиметься вижити в умовах складного та насиченого зовнішнього середовища. Тобто можна відмітити, щзо асортиментна політика виступає певним орієнтиром для прийняття рішень щзо відповідають вимогам умов функціонування суб'єкта ринку. Таким чином обрана тема є дуже актуальною в умовах ринкової економіки. Мета дослідження - вивчення особливостей сучасної асортиментної політики підприємств в умовах висококонкурентного ринку та розроблення заходів щзодо управлінських рішень у сфері асортиментної політики підприємства. Для досягнення мети необхідно виконати такі завдання: вивчити теоретичні аспекти управління асортиментною політикою підприємства; визначити основні методи формування асортименту продукиї підприємства; проаналізувати методи асортиментної політики за критеріями управлінської ефективності; намітити заходи покращення асортиментної політики підприємства. 3 метою дослідження формування асортименту продукиї підприємства викори товувались три основні групиметодів: методи економічного аналізу; методи визначення споживчих переваг; методи портфельного аналізу. Обєктом дослідження є ПрАТ “Вінницька харчосмакова фабрика”, яка виробляє більше 50 найменувань продукиї: хрін столовий; гірчиця; майонез; соуси; кетчуп; круп'яні палички; сухі сніданки з наповнювачами; каші швидкого готування; борошно текстуроване; хлібний квас; оцет столовий “Вінницький”; пет тара. Всі процеси виробництва здійснюються на сучасному, високотехнологічному устаткуванні провідних європейських компаній у строгій відповідності з рецептурою й дотриманням всіх державних стандартів. В результаті проведеного аналізу АВС-рейтингу всіх товарів ПрАТ “Вінницъька харчосмакова фабрика” було встановлено, щчо у 2017 рочі до стратегічної групи виробництва - група А - увійшов такий види продукиіі, як хрін, гірчиця, соуси. Приведена група продукиї приносить більще 78\% виручки в досліджуваному підприємстві. До групи В відноситься виробництво круп. Дана група приносить підприємству 15,7\% від загальної виручки. Останні види продукиії, котрі входять до групи С, суттєво не впливають на загальну виручку від реалізації. Для підприємства існують три основних напрямки набуття конкурентних переваг: стати самому крашим, послабити конкурентів або змінити ринкове середовище. Розроблена матриия SWOT-аналізу дозволяє сформулювати перелік першочергових заходів, які повинна провести компанія для вдосконалення своєї маркетингової середовища. Враховуючи сильні та слабкі сторони ПрАТ “Вінницька харчосмакова фабрика” та поєднуючи їх з визначеними можливостями можна намітити наступні стратегії розвитку товариства: розширення асортименту та номенклатури продукції; розвиток системи персональних продажів для оптових покупців продукції; створення і пощирення безкоштовних рекламно-інформаційних матеріалів про діяльність підприємства та проведення рекламної компанї; збільшення ринкової частки компанії за рахунок створення нових товарів і завоювання нових сегментів ринку.

Ключові слова: управління, асортиментна політика, товар, товарний асортимент, якість, номенклатура, концепція, стратегія, маркетинг, сегмент ринку, ринкове середовище.

\section{Вступ}

На сучасному етапі, ринкові відносини пред'являють підвищені вимоги до формування та раціонального управління асортиментом споживчих товарів, що служить одним з критеріїв конкурентоспроможності підприємств.

Під управлінням асортиментом товарів розуміють діяльність, спрямовану на приведення асортименту у відповідність 3 вимогами його раціональності. Асортимент споживчих товарів має бути різноманітним та різнитися походженням, призначенням, умовами зберігання різних видів товарів, що спонукає до появи такої важливої функції асортименту, як систематизація всієї безлічі груп, підгруп, видів і різновидів товарів (Troian, 2014).

На думку Ф. Котлера, асортимент дуже вузький, якщо можна збільшити прибуток, доповнивши його новими виробами, і дуже широкий, якщо прибуток можна збільшити, скоротивши його. Отже, вибір тієї або іншої асортиментної стратегії повинен грунтуватися на оцінці змін грошових потоків, викликаних зміною асортименту, а також на підставі прогнозу стану грошових потоків у перспективі (Kotler \& Keller, 2008).

Основними елементами управління асортиментом $\epsilon$ встановлення вимог до його раціональності, визначення асортиментної політики підприємства. Вимоги до раціональності асортименту змінюються залежно від кон'юнктури ринку, тобто рівня платоспроможності покупця, правових, соціально-економічних та соціально-культурних характеристик навколишнього середовища підприємства.

Від результатів впровадження асортиментної політики буде залежати чи підприємство матиме можливість стабільно розвиватися, чи займатиме лідируючі позиції на ринках, спроможне ефективно конкурувати чи потрапить у кризу через невдало підібраний асортимент та намагатиметься вижити в умовах складного та насиченого зовнішнього середовища. Тобто можна відмітити, що асортиментна політика виступає певним орієнтиром для прийняття рішень що відповідають вимогам умов функціонування суб'єкта ринку.

Таким чином обрана тема $є$ дуже актуальною в умовах ринкової економіки.

В сучасній економічній науці окремі аспекти 3 питань формування асортиментної політики підприємств досліджували вітчизняні і зарубіжні вчені, зокрема А.В. Акофф, В.А. Алексунін, А.Н. Асаул, В.А. Афанас'єв, Г.Л. Багієв, А.Ф. Баришев, Л.А. Бірман, А.В. Войчак, С.С. Гаркавенко, Л.Д. Гармідер, Є.П. Голубков, О.П. Градов, Г.Е. Дихтль, П.С. Зав'ялов, В.В. Зотов, В.А. Книшова, Г.Н. Кобзєв, Ф. Котлер, Ф.А. Крутикова, Л.О. Лігоненко, І.А. Маркіна, А.А. Мазаракі, О.I. Марченко, А.В. Міщенко, М.А. Окландер, А.В. Орлов, Х. Хершген та ін.

В той же час, швидкі темпи зміни ринкових умов вимагають постійного перегляду підходів до системи прийняття рішень 3 асортименту товарів підприємства та ії̈ відповідності новим умовам господарювання.

Мета дослідження - вивчення особливостей сучасної асортиментної політики підприємств в умовах висококонкурентного ринку та розроблення заходів щодо управлінських рішень у сфері асортиментної 
політики підприємства.

Для досягнення мети необхідно виконати такі завдання: вивчити теоретичні аспекти управління асортиментною політикою підприємства; визначити основні методи формування асортименту продукції підприємства; проаналізувати методи асортиментної політики за критеріями управлінської ефективності; намітити заходи покращення асортиментної політики підприємства.

\section{Матеріал і методи досліджень}

Формування асортименту може здійснюватися різними методами і підходами залежно від масштабів збуту, властивостей товарів, комерційних і соціальних цілей і завдань, що стоять перед підприємством.

Методи формування асортименту продукції підприємства можна поділити на три основні групи:

- методи економічного аналізу;

- методи визначення споживчих переваг;

- методи портфельного аналізу (Kubyshyna \& Samokhvalova, 2006).

До економічних методів належить такі методи, як, аналіз ABC-XYZ, який базується на підставі принципу Парето, тобто 20\% усіх товарів дають $80 \%$ обігу. Тобто необхідно концентрувати ресурси на тій малій частині, яка дуже вважлива, а не на величезній частині другорядного. На підставі цього методу визначається АВС-рейтинг всіх товарів з групи, що аналізується, та на його основі ухвалюються рішення про зміни і розвиток в товарному портфелі. Цей метод дає змогу класифікувати ресурси фірми за ступенем їх важливості, визначити значення товарної групи, норматив товарного запасу та частоту замовлення товару. Даний метод був використаний при проведені досліджень.

До методів визначення споживчих переваг належать: модель Розенберга - модель 3 ідеальною точкою, модель “продукт - ринок”, багатомірні методи (факторний i кластерний аналізи, які використовуються для обгрунтування маркетингових рішень).

До третьої групи належать методи аналізу життевого циклу товару і портфельного аналізу. До цієї групи відносять матрицю McKinsey, або General Electric - метод, який широко застосовується для аналізу поточних ринкових ситуацій “привабливість конкурентоспроможність".

\section{Результати та їх обговорення}

Процес формування асортименту полягає у плануванні фактично всіх видів діяльності, спрямованих на відбір продуктів для майбутнього виробництва й реалізації на ринку. Даний процес безперервний, він триває на протязі усього життєвого циклу продукту, від моменту виникнення задуму до вилучення його із товарної програми.

Зазвичай асортиментна політика планується на довгостроковий період.

При формуванні асортименту враховуються наступні фактори, рис. 1.

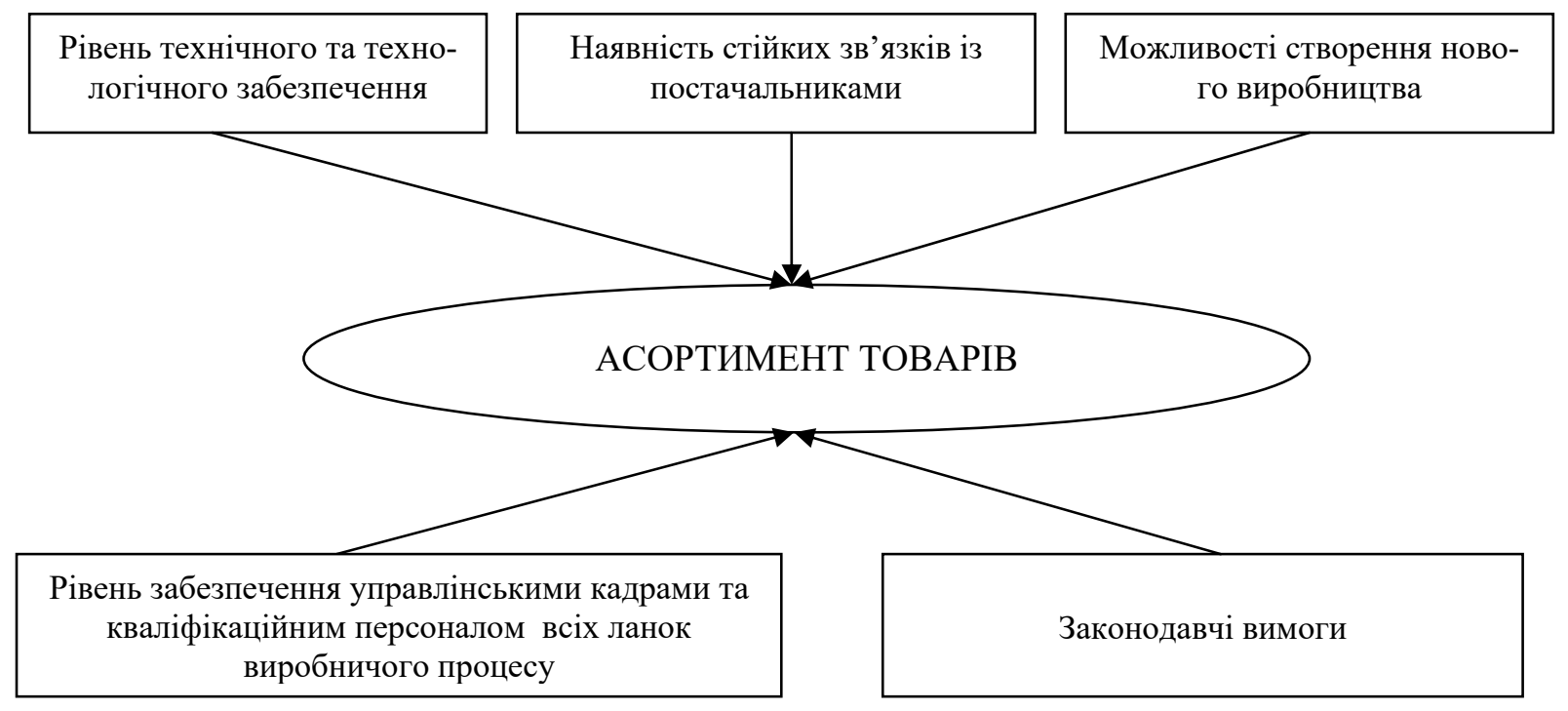

Рис. 1. Фактори впливу на асортимент товарів

Проте, формування оптимального для підприємства асортименту ускладнюється наступними факторами:

- широким асортиментом товарів;

- врахування законодавчих вимог щодо наявності обов'язкового асортименту;

- ускладненням розрахунків реальної потреби населення в тих чи інших товарах;

- раптовістю появи нових модифікацій товару.
У зв'язку з чим, прогнозування та планування асортименту товарів у даних умовах, може бути лише короткостроковим. Тому, формування та оптимізація асортименту це щоденний процес, що базується на аналізі пропозиції постачальників (виробничих підприємств оптової торгівлі) і щоденних роздрібних продаж.

На сьогоднішній день, ПрАТ “Вінницька харчосмакова фабрика” виробляє більше 50 найменувань 
продукції: хрін столовий; гірчиця; майонез; соуси; кетчуп; круп'яні палички; сухі сніданки з наповнювачами; каші швидкого готування; борошно текстуроване; хлібний квас; оцет столовий “Вінницький”; пет тара.

Всі процеси виробництва здійснюються на сучасному, високотехнологічному устаткуванні провідних європейських компаній у строгій відповідності з рецептурою й дотриманням всіх державних стандартів.

Одним із факторів розвитку виробництва $є$ поглиблення його спеціалізації та концентрації на основі збільшення розмірів виробництва.

Виробництво і реалізація конкурентоспроможної продукції - обов'язкова умова конкурентоспроможності підприємства. Тому для забезпечення конкурентоспроможності підприємства необхідно систематично проводити роботу 3 усього виробничогосподарського циклу, що призводить до конкурентних переваг у сфері науково-дослідної роботи, виробництва, управління, фінансів, маркетингу тощо.
Аналіз АВС-рейтингу всіх товарів групи базується на використанні результативних показників, які відображають ефективність виробництва продукції, 3 допомогою цього методу. Такий аналіз надає можливість визначити основні стратегічні види продукції на підприємстві протягом досліджуваного періоду та $є$ основою подальшої конкурентної стратегії підприємства. Аналіз проводиться на основі дослідження кумулятивної структури виручки від реалізації продукції за останній рік.

Дані АВС - аналізу відображено в таблиці 1.

АВC - аналіз визначає вагу кожного виду продукції у загальному асортименті. До групи А належать види продукції, асортиментна кількість яких не перевищує $80 \%$ вартості у структурі реалізації. Група В має проміжне становище: вартість у структурі реалізації - лише 15\%. До групи С входять види продукції вартість яких у структурі виробництва становить лише $5 \%$.

\section{Таблиця 1}

АВС аналіз рейтингу продукції ПрАТ “Вінницька харчосмакова фабрика”, 2017 р.

\begin{tabular}{|c|c|c|c|c|c|}
\hline \multirow{2}{*}{ Показники } & \multicolumn{2}{|c|}{ Виручка від реалізації } & \multirow{2}{*}{ Питома вага } & \multirow{2}{*}{ Кумулятивна виручка від реалізації } & \multirow{2}{*}{ Групг } \\
\hline & тис.грн. & $\%$ & & & \\
\hline Хрін, горчиця, соуси & 31285 & 78,5 & 78,5 & 76,4 & A \\
\hline Крупи & 5858 & 15,7 & 15,7 & 17,7 & B \\
\hline Пет тара & 510 & 3,7 & 47 & 3,4 & $\mathrm{C}$ \\
\hline Інша продукція & 111 & 1,0 & 4,7 & 1,5 & \\
\hline Всього по підприємству & 39853 & 100 & 100 & 100 & \\
\hline
\end{tabular}

Отже, у ПрАТ “Вінницька харчосмакова фабрика” у 2017 році до стратегічної групи виробництва - група А - увійшов такий види продукції, як хрін, гірчиця, соуси. Приведена група продукції приносить більше 78\% виручки в досліджуваному підприємстві, що становить 31285 тис. грн.

До групи В відноситься виробництво круп. Дана група приносить підприємству $15,7 \%$ від загальної виручки. Останні види продукції, котрі входять до групи C, суттєво не впливають на загальну виручку від реалізації.

Успіх у конкурентній боротьбі підприємству забезпечують його конкурентні переваги - порівняльні динамічні характеристики підприємства, які забезпечують його конкурентостійкість та конкурентогнучкість.
Для підприємства існують три основних напрямки набуття конкурентних переваг: стати самому кращим, послабити конкурентів або змінити ринкове середовище. У першому випадку підприємство застосовує сукупність заходів, таких як поліпшення якості продукції, зниження іiі собівартості, направлених на вдосконалення власної діяльності. У другому випадку діяльність підприємства спрямована на безпосереднє послаблення конкурентів методами, які набули широкого застосовуються у вітчизняній практиці. У випадку, коли неможливо використати два перших методи, часто намагаються змінити саме середовище, в якому вони конкурують.

Щоб представити фахівця всю необхідну інформацію для визначення можливих стратегій та їх комбінацій необхідно провести SWOT-аналіз (табл. 3, 4).

Таблиця 2

Експертні оцінки конкурентних позицій ПрАТ “Вінницька харчосмакова фабрика”, 2017 р.

\begin{tabular}{|c|c|c|c|c|}
\hline \multirow{2}{*}{ Характеристики позиції у конкуренції } & \multirow{2}{*}{ Вага } & \multicolumn{3}{|c|}{ Продукція } \\
\hline & & хрін & крупи & пет тара \\
\hline відносна позиція на ринку & 0,2 & 10 & 5 & 7 \\
\hline відносний потенціал виробництва & 0,25 & 10 & 4 & 6 \\
\hline відносний потенціал інновацій & 0,35 & 9 & 4 & 7 \\
\hline відносний потенціал персоналу & 0,2 & 8 & 6 & 8 \\
\hline всього & 1 & 8,25 & 4,6 & 6,5 \\
\hline
\end{tabular}




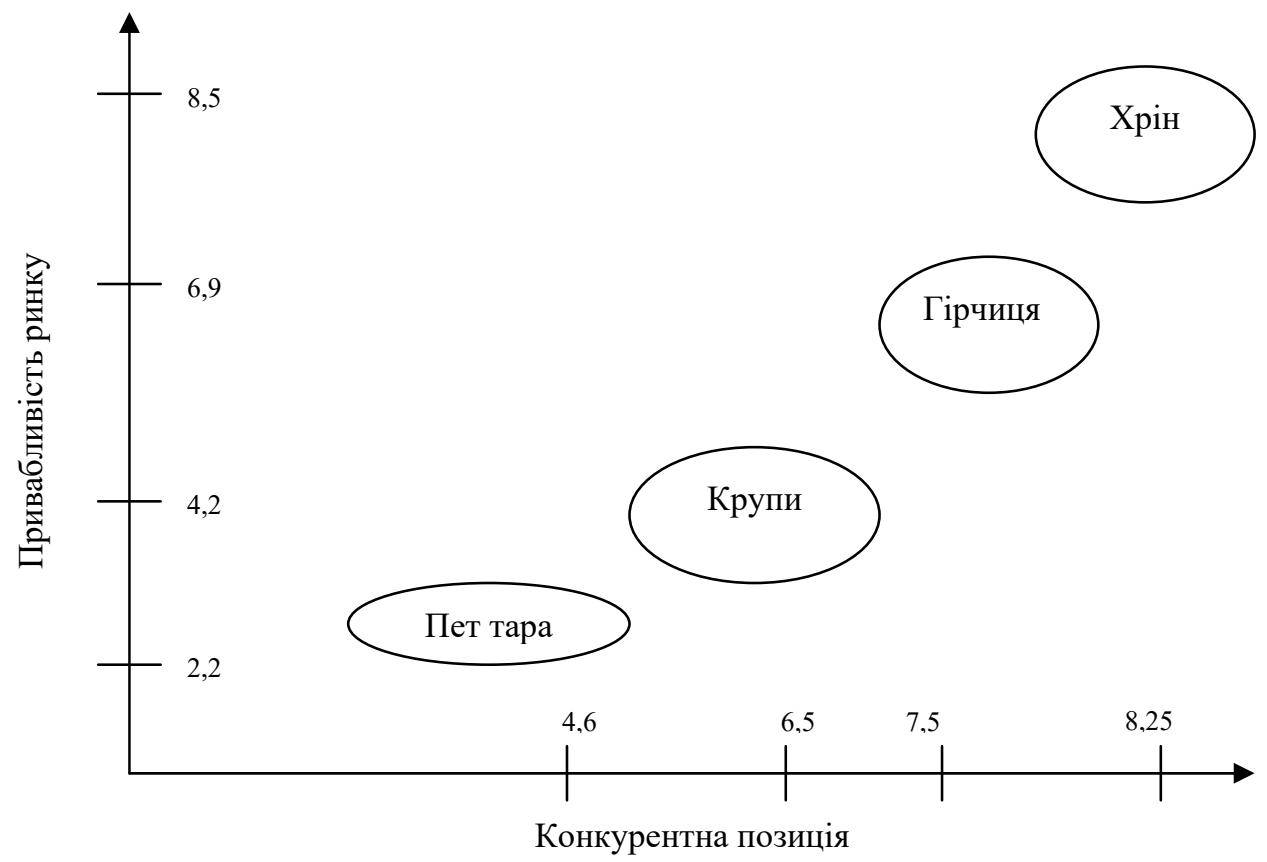

Рис. 2. Матриця Мак Кінсі-Дженерал-Електрик

Таблиця 3

Матриця SWOT-аналізу організації ПрАT “Вінницька харчосмакова фабрика”

Сильні сторони (S)

1. Великий досвід роботи на ринку

2. Високий рівень організації управлінського обліку

3. Наявність висококваліфікованого виробничого персоналу та новітніх технологій

4. Високий рівень контролю якості прподукції

5. Значні виробничі потужності
Слабкі сторони (W)

1. Недостатній рівень клієнтського сервісу

2. Недостатні інноваційні можливості

3. Середня позиція в долі ринку

4. Стиль керівництва і структура компанії неадекватні ринковій ситуації

5. Відсутність системи стратегічного планування

\section{Таблиця 4}

Можливості і загрози в діяльності ПрАТ “ВХСФ”

\begin{tabular}{|c|c|c|}
\hline Фактори & $\begin{array}{c}\text { Оцінка ступеня впливу } \\
\text { фактора в балах }\end{array}$ & $\begin{array}{c}\text { Можливі варіанти відповідних дій } \\
\text { підприсмства }\end{array}$ \\
\hline \multicolumn{3}{|c|}{ Можливості } \\
\hline 1.Можливість вертикальної інтеграції & 3 & $\begin{array}{l}\text { Розробка і реалізація нових продуктів для } \\
\text { власної збутової мережі }\end{array}$ \\
\hline $\begin{array}{l}\text { 2.Статистичність конку-рентного } \\
\text { середовища }\end{array}$ & 2 & $\begin{array}{l}\text { Посилення залежності спо-живачів від } \\
\text { підприємства }\end{array}$ \\
\hline 3. Послаблення позицій постачальників & 2 & Можливість закупівель у інших постачальників \\
\hline 4. Можливості розши-рення збуту & 3 & Розширення номенклатури \\
\hline \multicolumn{3}{|c|}{ Загрози } \\
\hline 1. Посилення конкурен-тного тиску & 3 & Зниження цін, покращення сервісу \\
\hline $\begin{array}{l}\text { 2. Сповільнення зростання ринку товарів } \\
\text { номен-клатури підприємства }\end{array}$ & 2 & Посилення уваги на зайнятий сегмент \\
\hline 3. Посилення позицій конкурентів & 3 & $\begin{array}{l}\text { Покращення якості товарів, розширення асор- } \\
\text { тименту }\end{array}$ \\
\hline
\end{tabular}

Розроблена матриця SWOT-аналізу дозволяє сформулювати перелік першочергових заходів, які повинна провести компанія для вдосконалення своєї маркетингової середовища.

\section{Висновки}

Враховуючи сильні та слабкі сторони ПрАТ “Вінницька харчосмакова фабрика" та поєднуючи їх 3 визначеними можливостями можна намітити наступні стратегії розвитку товариства: 
1. Розширення асортименту та номенклатури продукції;

2. Розвиток системи персональних продажів для оптових покупців продукції;

3. Створення і поширення безкоштовних рекламно - інформаційних матеріалів про діяльність підприємства та проведення рекламної компанії;

4. Збільшення ринкової частки компанії за рахунок створення нових товарів і завоювання нових сегментів ринку.

\section{References}

Kotler, F., \& Keller, K.L. (2008). Marketynh menedzhment. SPb.: Pyter (in Ukrainian).

Kubyshyna, N.S., \& Samokhvalova, Ye.O. (2006). Stratehichni aspekty formuvannia asortymentu tovariv na promyslovomu rynku. Stratehii innovatsiinoho rozvytku pidpryiemstv Ukrainy: Zbirnyk naukovykh prats. K.: Kyivskyi natsionalnyi universytet tekhnolohii ta dyzainu, 24 (in Ukrainian).

Troian, A.V. (2014). Osoblyvosti asortymentnoi polityky pidpryiemstva $\mathrm{V}$ suchasnykh umovakh hospodariuvannia. Efektyvna ekonomika, 1. Rezhym dostupu: http://www.economy.nayka.com.ua/?op=1\&z=2708 (in Ukrainian). 